\title{
Typifications in Passiflora L. (Passifloraceae) described by Frei José Mariano da Conceição Vellozo
}

\section{Michaele Alvim Milward-de-Azevedo'}

Received: April 5, 2017

Accepted: June 5, 2017

\begin{abstract}
This work presents 19 lectotypifications and one epitype for the genus Passiflora (Passifloraceae sensu stricto) described by Frei José Mariano da Conceição Vellozo in Flora Fluminensis. The original illustrations are designated as lectotypes. Passiflora obtusa is here proposed to be a synonym of P. porophylla.
\end{abstract}

Keywords: Brazil, Flora Fluminensis, epitype, lectotype, nomenclature, passionflower

\section{Introduction}

"Flora Fluminensis" is considered one of the first compilations of Brazilian flora (Knapp et al. 2015), and was the result of pioneering surveys of plants in the state of Rio de Janeiro and some parts of the state of São Paulo, when the state of Rio de Janeiro had not yet been defined (Damasceno 1977; Lima 1995; Knapp et al. 2015). Led by Frei José Mariano da Conceição Vellozo during the $18^{\text {th }}$ century (1782-1790), Flora Fluminensis provided 1,639 succinct descriptions and botanical illustrations of diagnostic characters distributed among 11 volumes, which were effectively published 39 years later, leading to the loss of authorship of many genera and species (Cervi \& Rodrigues 2010; Bediaga \& Lima 2015).

According to Borgmeier (1937) and Carauta (1973), Flora Fluminensis was published over three different time periods: the text was printed in 1825 and distributed in 1829; the illustrations were edited in 1827 and published 1831; and the species descriptions were printed in 1881.

Vellozo's morphological descriptions usually mentioned the place of collection and popular or indigenous names and uses, and followed the sexual classification system proposed by Linnaeus (Kury 2015), but without indicating vouchers (Lima 1995). These factors have made it difficult to identify these species, and many names have since been treated as problematic or altogether ignored by science (Knapp et al. 2015).

According to Kury (2015), the illustrations of Flora Fluminensis, especially of the reproductive parts of flowers, serve as valuable references because no information exists regarding herbarium or type material fixed to species names. Prior to the $20^{\text {th }}$ century, modern rules of the International Code of Botanical Nomenclature were not in force, thus adding even more value to the illustrations. Braga (2005) points out that Vellozo does not mention the existence of watercolors or living or herbarium material, and that he only had access to monochromatic versions of the illustrations.

Binomials were included in Flora Fluminensis along with descriptions of new species, as examined by Cervi \& Rodrigues (2010) in their study of the species names, diagnoses, and illustrations in Volume 9.

Due to the absence of type material, and according to Art. 9.11 of the International Nomenclature Code for algae, fungi

\footnotetext{
${ }^{1}$ Departamento de Ciências do Meio Ambiente, Instituto Três Rios, Universidade Federal Rural do Rio de Janeiro, Av. Prefeito Alberto da Silva Lavinas 1847, Centro, 25802-100, Três Rios, RJ, Brazil, michaelemilward@gmail.com
} 
and plants (McNeill et al. 2012), it is necessary to designate lectotypes for these species. Recently, lectotypifications for the species described and illustrated by Vellozo were undertaken by Lima (1995), Braga (2005), Lack (2012), Buzatto et al. (2013), Pastore (2013), Porter-Utley (2014), Knapp et al. (2015), Pellegrini (2015), Pellegrini et al. (2015) and Svoboda et al. (2016).

In the revisions of the Brazilian species of Passiflora L. (Passifloraceae sensu stricto) by Cervi (1997; 2000), and Milward-de-Azevedo et al. (2012), many names were evaluated, among which were those for species described by Vellozo, but these authors did not assign lectotypes. Portey-Utley (2014) performed a revision of the Passiflora subgenus Decaloba (DC.) Rchb. supersection Cieca (Medik.) J.M. MacDougal \& Feuillet, and established lectotypes for P. globosa and P. oliviformis, both originally described by Vellozo (1831/1881), and both synonyms of P. subersosa L. subsp. litoralis (Kunth) Port.-Utl. ex M.A.Milward-deAzevedo, J.F.Baumgratz \& V.Gonçalves-Esteves. Svoboda et al. (2016) typified the species Passiflora subgenus Passiflora section Dysosmia DC., P. foetida, described by Vellozo, as synonymous with P. foetida var. fluminensis (M. Roem) Killip, and P. villosa.

In Flora Fluminensis, Vellozo (1831/1881) named 25 species of Passifloraceae, all belonging to the genus Passiflora. Cervi \& Rodrigues (2010) reviewed these species based on prints and Latin diagnoses, but did not typify the names. They accepted six of the species as valid $(P$. mediterranea, $P$. ovalis, $P$. porophylla, $P$. silvestris, $P$. tetraden and $P$. villosa), considered sixteen species to be synonyms (P. arvensis, $P$. bilobata, $P$. dentata, $P$. diaden, $P$. foetida, $P$. globosa, P. lunata, P. maliformis, P. oliviformis, P. pallida, P. pertusa, . polyaden, $P$. quadrangularis, $P$. rubra, $P$. sururuca and $P$. violacea), recognized $P$. edulis Sims and $P$. racemosa Brot. as correctly identified; and considered the species Passiflora obtusa as incertae sedis.

Subsequent studies have involved analyses of protologues and illustrations of the species of Passifloraceae described by Vellozo, which ha sled to the detection of various nomenclatural problems, mainly regarding typification and synonymy, which are addressed here.

\section{Materials and methods}

The brief descriptions of this work were based on digital images of all original illustrations of Passiflora available through the website of the Biblioteca Nacional (http://bndigital.bn.br/acervodigital), and the published illustrations and descriptions from Flora Fluminensis (1831/1881) available through the Biodiversity Heritage Library (http://www.biodiversitylibrary.org/). Terminology followed Rizzini (1977) and Stearn (2004), and geographical references, when cited in species descriptions, were based on the interpretations of Lima (1995).

\section{Results and discussion}

Nineteen lectotypifications and one epitype for species described by Vellozo, which have not yet been typified, are provided in accordance with the guidelines established by the Melbourne Code (McNeill et al. 2012). The illustrations of these species are considered valid publications because the names are accompanied by analyses in accordance with articles 38.8 and 38.9 of Melbourne Code (McNeill et al. 2012).

The validations of P. pertusa and P. polyadena were performed together with the description of 1881 , because only the vegetative parts were illustrated in 1831 and so did not meet the requirements for identification.

\section{Typifications and taxonomy}

1. Passiflora alata Curtis, Botanical Magazine 1: 66, fig. 66. 1790.

= Passiflora maliformis Vell., Fl. Flumin. 9, fig. 73. 1831 (“1827”); Arch. Mus. Nac. Rio de Janeiro 5: 376. 1881. Lectotype (designated here): Brazil. [Rio de Janeiro or São Paulo]: "maritimis e mediterraneis"; [illustration] Original parchment plate of Flora Fluminensis in the Manuscript Section of the Biblioteca Nacional, Rio de Janeiro [cat. no.: mss1198658_077] and later published in Vellozo, Fl. flumin. 9, fig. 73, 1831.

= Passiflora quadrangularis Vell., Fl. Flumin. Icon. 9: tab. 76. 1831 ('1827'); Arch. Mus. Nac. Rio de Janeiro 5: 377. 1881. Lectotype (designated here): Brazil. [Rio de Janeiro or São Paulo]: "tum maritimis, cum mediterraneis"; [illustration] Original parchment plate of Flora Fluminensis in the Manuscript Section of the Biblioteca Nacional, Rio de Janeiro [cat. no.: mss1198658_080] and later published in Vellozo, Fl. flumin. 9, fig. 76, 1831.

Curtis (1790) describes and illustrates P. alata with a quadrangular-alate stem; lanceolate to ovate stipules and bracts; leaves with petioles with two pairs of urceolate glands, ovate blades, acute apex and cordate base; and flowers with aristate sepals, red petals and white, red, and lilac banded external filaments of the corona.

The illustration of $P$. maliformis clearly shows a quadrangular stem; ovate stipules; leaves with petioles with one pair of glands, ovate blades, acute apex and cordate base; flower with coronal filaments banded, and ellipsoid fruit. Passiflora quadrangularis, exhibits quadrangular-alate stem; ovate stipules; leaves with petioles with two pairs of glands, blades oblonglanceolate, apex acuminate, base truncate, bracts ovate, flowers with aristate sepals, and fruits piriform. The illustrations and descriptions of both $P$. maliformis and P. quadrangularis are very similar, as confirmed by Cervi \& Rodrigues (2010). They occur in coastal restingas and forest edges where P. alata is frequent (Cervi 1997). 
Passiflora maliformis was synonymized by Killip (1938) and P. quadrangularis by Cervi \& Rodrigues (2010).

2. Passiflora amethystina J.C. Mikan, Delectus Florae et Faunae Brasiliensis 20. 1820.

= Passiflora violacea Vell., Fl. Flumin. 9, fig. 84. 1831 (“1827”); Arch. Mus. Nac. Rio de Janeiro 5: 379. 1881. Lectotype (designated here): Brazil. [Rio de Janeiro or São Paulo]: "silvis maritimis"; [illustration] Original parchment plate of Flora Fluminensis in the Manuscript Section of the Biblioteca Nacional, Rio de Janeiro [cat. no.: mss1198658_088] and later published in Vellozo, Fl. flumin. 9, fig. 84, 1831.

Mikan (1820) describes and illustrates P. amethystina as a herbaceous vine, with falcate or semicordate stipules; leaves with petioles with 3-7 glands, blades trilobate, apex acute and base cordate; flower single, with aristate sepals and corona with 8 series of filiform filaments. The illustration of $P$. violocea clearly shows oblong-lanceolate asymmetrical stipules; leaves with petioles with 6 glands, trilobate leaf blades, lanceolate lobes, acute apex, cordate base and lanceolate bracts; flowers with aristate sepals, and oblong-lanceolate fruits with three carpels. Occurs in florest formations of the coastal plain. The illustration and description presented by Vellozo (1831/1881), are very similar to the illustration and description of $P$. amethystina, as already synonymized by Cervi (1997) and confirmed by Cervi \& Rodrigues (2010).

3. Passiflora capsularis L., Species Plantarum 2: 957.1753.

= Passiflora bilobata Vell., Fl. flumin. 9, fig. 78. 1831 (“1827”); Arch. Mus. Nac. Rio de Janeiro 5: 378. 1881. Decaloba bilobata (Vell.) M.Roem., Prospect. Fam. nat. syn. monogr. 2: 154. 1846. Lectotype (designated here): Brazil. [Rio de Janeiro or São Paulo]: "maritimis"; [illustration] Original parchment plate of Flora Fluminensis in the Manuscript Section of the Biblioteca Nacional, Rio de Janeiro [cat. no.: mss1198658_082] and later published in Vellozo, Fl. flumin. 9, fig. 78, 1831.

= Passiflora lunata Vell., Fl. flumin. 9, fig. 80. 1831 (“1827”); Arch. Mus. Nac. Rio de Janeiro 5: 378. 1881. Lectotype (designated here): Brazil. [Rio de Janeiro or São Paulo]: "campis mediterraneis transalpinis"; [illustration] Original parchment plate of Flora Fluminensis in the Manuscript Section of the Biblioteca Nacional, Rio de Janeiro [cat. no.: mss1198658_084] and later published in Vellozo, Fl. flumin. 9, fig. 80, 1831.

Despite the brief description by Linnaeus (1753), $P$. capsularis was described as a species with petiolate leaves, bilobate and cordate leaf blade; and reddish fruit. The illustrations and descriptions by Vellozo (1831/1881) demonstrate that the species P. bilobata and P. lunata are synonymous with $P$. capsularis, as confirmed and synonymized by Milward-de-Azevedo et al. (2012), and not synonymous with P. cervii Milward-de-Azevedo or P. rubra L., species with great morphological affinity. Passiflora cervii is distinguished by leaf blades trilobate to the apex; flowers with ligulate corona filaments, and ovate fruits. Passiflora rubra is distinguished by having flowers with hirsute ovaries and ovate fruits; it also does not occur in the Southeast Region of Brazil.

The illustrations of P. bilobata and P. lunata show a pubescent indument, linear-subulate stipules; bilobate leaf blades, petiolar glands and ocelli absent; flowers without pedicels and uniseriate corona. Passiflora bilobata also exhibits fusiform capsular fruit. The taxa occur in coastal vegetation, including formations of the Paraíba do Sul river and the Mantiqueira Mountains (Serra da Mantiqueira).

4. Passiflora edulis Sims, Botanical Magazine 45: pl. 1989. 1818.

= Passiflora diaden Vell., Fl. Flumin. 9, fig. 90. 1831 (“1827"); Arch. Mus. Nac. Rio de Janeiro 5: 380. 1881. Lectotype (designated here): Brazil. [Rio de Janeiro or São Paulo]: "silvis maritimis"; [illustration] Original parchment plate of Flora Fluminensis in the Manuscript Section of the Biblioteca Nacional, Rio de Janeiro [cat. no.: mss1198658_094] and later published in Vellozo, Fl. flumin. 9, fig. 90, 1831.

Sims (1818), describes and illustrates P. edulis as a herbaceous vine with linear-subulate stipules; leaves with petioles with one pair of glands, trilobate leaf blades, acute apex, cordate base, serrate margin, ovate bracts, solitary flower with aristate sepals and fruit a globose berry. The illustration of $P$. diaden shows leaves with petioles with one pair of glands, trilobate leaf blades with glands between the sinus, acute to obtuse apex, cordate base and serrate margin, ovate bracts with denticulate margin; and solitary flowers. The illustration and description by Vellozo (1831/1881), are very similar to the illustration and description of $P$. edulis, as already synonymized by Cervi (1997) and confirmed by Cervi \& Rodrigues (2010).

5. Passiflora foetida var. foetida L., Species Plantarum 2: 959. 1753.

= Passiflora polyadena Vell., Fl. Flumin. 9, fig. 92. 1831 (“1827"); Arch. Mus. Nac. Rio de Janeiro 5: 381. 1881. Lectotype (designated here): Brazil. [Rio de Janeiro or São Paulo]: "collibus maritimis prope urbem"; [illustration] Original parchment plate of Flora Fluminensis in the Manuscript Section of the Biblioteca Nacional, Rio de Janeiro [cat. no.: mss1198658_096] and later published in Vellozo, Fl. flumin. 9, fig. 92, 1831

Despite the brief description by Linnaeus (1753), P. foetida was described as a species with trilobate leaf blades, cordate base, villous indument and pinnatisect bracts. Passiflora foetida is distinguished by pinnatisect stipules and bracts. The illustration of P. polyadena shows a vine with villous indument, glandular pinnatisect stipules, leaf blade trilobate to the apex, acute apex, cordate base, and pinnatisect glandular bracts. 
There is no illustration of the flower and fruit, however, in the description published in 1881, Vellozo mentioned a terminal racemose inflorecence, flowers with scarlet petals, and fruits as ovate berries, which demonstrates the similarity with $P$. foetida var. foetida, as already confirmed and synonymized by Cervi \& Rodrigues (2010).

6. Passiflora kermesina Link \& Otto, Verhandlungen des Vereins zur Beförderung des Gartenbaues in den Königlich Preussischen Staaten 2: 403, t. 15. 1826.

= Passiflora dentata Vell. Fl. Flumin. 9, fig. 94.1831 (“1827”); Arch. Mus. Nac. Rio de Janeiro 5: 381. 1881. Lectotype (designated here): Brazil. [Rio de Janeiro]: "collibus maritimis prope urbem"; [illustration] Original parchment plate of Flora Fluminensis in the Manuscript Section of the Biblioteca Nacional, Rio de Janeiro [cat. no.: mss1198658_098] and later published in Vellozo, Fl. flumin. 9, fig. 94, 1831.

Passiflora kermesina presents reniform stipules; leaves with petioles with 2-4 glands, trilobate leaf blades, acute to obtuse apiculat eapex, cordate to truncate base, dentate margin, linear bracts; and reddish solitary flowers. Passiflora dentata was considered synonymous with $P$. kermesina, as already synonymized by Killip (1938) and confirmed by Cervi \& Rodrigues (2010), because the illustration and description by Vellozo (1831/1881) presents semi-cordate asymmetrical stipules, leaves with petioles with glands, trilobate leaf blades, acute apex, cordate to rounded base, dentate margin; and solitary flowers.

7. Passiflora mediterranea Vell., Fl. Flumin. 9, fig. 72. 1831 (“1827”); Arch. Mus. Nac. Rio de Janeiro 5: 376. 1881. Lectotype (designated here): Brazil. [Rio de Janeiro or São Paulo]: "fruticetis mediterraneis transalpinis"; [illustration] Original parchment plate of Flora Fluminensis in the Manuscript Section of the Biblioteca Nacional, Rio de Janeiro [cat. no.: mss1198658_076] and later published in Vellozo, Fl. flumin. 9, fig. 72, 1831.

Frequently identified as $P$. jilekii Wawra, described in 1863 , the name $P$. mediterranea has priority, as already established by Cervi \& Rodrigues (2010), in accordance with articles 38.8 and 38.9 of Melbourne Code (McNeill et al. 2012). Passiflora mediterranea has reniform stipules; oblique leaves with petioles with 7 glands, ovate leaf blades, acute apex, cordate base, entire margin, ovate bracts; and reddish solitary flowers solitary with scarlet petals. It occurs in vegetation formations along the Paraíba do Sul river and Mantiqueira Mountains (Serra da Mantiqueira).

8. Passiflora mucronata Lam., Encyclopédie Méthodique, Botanique 3: 33. 1789.

= Passiflora pallida Vell., Fl. Flumin. 9, fig. 70. 1831 (“1827”); Arch. Mus. Nac. Rio de Janeiro 5: 376. 1881. Lectotype (designated here): Brazil. [Rio de Janeiro or São Paulo]: "fruticetis maritimis ad loca arenosa"; [illustration]
Original parchment plate of Flora Fluminensis in the Manuscript Section of the Biblioteca Nacional, Rio de Janeiro [cat. no.: mss1198658_074] and later published in Vellozo, Fl. flumin. 9, fig. 70, 1831.

Lamarck (1789) described P. mucronata as a vine without indumentum and with cordate leaf blades and ovate stipules. The illustration of $P$. pallida shows ovate stipules, leaves with petioles with one pair of glands, ovate leaf blades, acute apex, rounded base and entire margin; and flowers with aristate sepals. The description adds information about the white color of the petals and the popular name "maracujás-dos-morcegos". Passiflora pallida was considered synonymous with $P$. mucronata, as already synonymized by Killip (1938) and confirmed by Cervi \& Rodrigues (2010). This species is very common in the restingas of the Northeast and Southeast regions of Brazil.

9. Passiflora ovalis Vell., Fl. Flumin. 9, fig. 75. 1831 (“1827”); Arch. Mus. Nac. Rio de Janeiro 5: 377. 1881. Lectotype (designated here): Brazil. [Rio de Janeiro]: "fruticetis maritimis"; [illustration] Original parchment plate of Flora Fluminensis in the Manuscript Section of the Biblioteca Nacional, Rio de Janeiro [cat. no.: mss1198658_079] and later published in Vellozo, Fl. flumin. 9, fig. 75, 1831. Epitype (designated here): Brazil, Rio de Janeiro, Paraty, Área de Proteção Ambiental do Cairuçu, Laranjeiras, estrada para a Praia do Sono, C. Duarte 88, 09/ VIII/1994 (RB 310926).

= Passiflora arvensis Vell., Fl. Flumin. 9, fig. 71. 1831 (“1827”); Arch. Mus. Nac. Rio de Janeiro 5: 376. 1881. Lectotype (designated here): Brazil. [Rio de Janeiro or São Paulo]: "silvis maritimis"; [illustration] Original parchment plate of Flora Fluminensis in the Manuscript Section of the Biblioteca Nacional, Rio de Janeiro [cat. no.: mss1198658_075] and later published in Vellozo, Fl. flumin. 9, fig. 71, 1831.

Frequently identified as Tetrastylis ovalis (Vell.) Killip, the name P. ovalis has priority because the genus Tetrastylis Barb. Rodr. was subordinated to the section Tetrastylis (Barb. Rodr.) Harms, subgenus Deidamioides (Harms) Killip (MacDougal \& Feuillet 2004).

Passiflora ovalis is characterized by elliptical to lanceolate leaf blades, racemose inflorescence, and flowers with four styles and ovary with four carpels. The illustration of $P$. ovalis shows leaves with petioles with one pair of glands, elliptical leaf blades, acute apex and base, entire margin and linear bracts; and racemose inflorescence and fruits as ellipsoid berries with four carpels. Three, not four, persistent styles were observed in the fruit. The flowers were not illustrated or described in Vellozo (1831/1881). Therefore, C. Duarte 88 (RB 310926) is designated as the epitype, considering that this material is quite representative of the floral morphology, thereby complementing the illustration of Vellozo, because the original illustration of $P$. ovalis is very rudimentary having only fruits. 
Passiflora arvensis was considered synonymous with $P$. ovalis, as already confirmed and synonymized by Cervi \& Rodrigues (2010), and exhibits lanceolate-ovate leaf blades, acute apex and base, entire margin; racemose inflorescence, and fruits as ellipsoidal berries. The description and illustration show the petiole to lack glands, which were probably overlooked by Vellozo (1831/1881) because they are adpressed.

10. Passiflora porophylla Vell., Fl. flumin. 9, fig. 82. 1831 (“1827”); Arch. Mus. Nac. Rio de Janeiro 5: 378. 1881. Cieca prophylla (Vell.) M.Roem., Prospect. Fam. nat. syn. monogr. 2: 147. 1846. Lectotype (designated here): Brazil. [RJ, Rio de Janeiro, Bairro de Santa Cruz]: "silvis maritimis Regii Praedii S. Crucis"; [illustration] Original parchment plate of Flora Fluminensis in the Manuscript Section of the Biblioteca Nacional, Rio de Janeiro [cat. no.: mss1198658_086] and later published in Vellozo, Fl. flumin. 9, fig. 82, 1831.

= Passiflora obtusa Vell., Fl. flumin. 9, fig. 81. 1831 (“1827”); Arch. Mus. Nac. Rio de Janeiro 5: 378. 1881. Decaloba obtusa (Vell.) M.Roem., Prospect. Fam. nat. syn. monogr. 2: 155. 1846. Lectotype (designated here): Brazil. [RJ, Rio de Janeiro, Bairro de Santa Cruz]: "silvis maritimis Regii Praedii S. Crucis"; [illustration] Original parchment plate of Flora Fluminensis in the Manuscript Section of the Biblioteca Nacional, Rio de Janeiro [cat. no.: mss1198658_085] and later published in Vellozo, Fl. flumin. 9, fig. 81, 1831. Syn. Nov.

= Passiflora pertusa Vell., Fl. flumin. 9, fig. 79. 1831 (“1827”); Arch. Mus. Nac. Rio de Janeiro 5: 378. 1881. Lectotype (designated here): Brazil. [Rio de Janeiro or São Paulo]: "collibus ad littora maris urbem"; [illustration] Original parchment plate of Flora Fluminensis in the Manuscript Section of the Biblioteca Nacional, Rio de Janeiro [cat. no.: mss1198658_083] and later published in Vellozo, Fl. flumin. 9, fig. 79, 1831.

= Passiflora rubra Vell., Fl. flumin. 9, fig. 77.1831 (“1827”); Arch. Mus. Nac. Rio de Janeiro 5: 377. 1881. Lectotype (designated here): Brazil. [Rio de Janeiro or São Paulo]: "silvis maritimis"; [illustration] Original parchment plate of Flora Fluminensis in the Manuscript Section of the Biblioteca Nacional, Rio de Janeiro [cat. no.: mss1198658_081] and later published in Vellozo, Fl. flumin. 9, fig. 77, 1831.

Frequently identified as P. organensis Gardner, described in 1845 , the name $P$. porophylla has priority, as already established by Cervi \& Rodrigues (2010), in accordance with articles 38.8 and 38.9 of Melbourne Code (McNeill et al. 2012). Passiflora porophylla has bilobate leaf blades with ocelli, acute apex and rounded base; flowers with corona of uniseriate dolabriform filaments, plicate operculum and fruits as globose berries.

Based on the illustration of leaf blades and habit without indument, and the morphological description and area of occurrence (littoral of Rio de Janeiro) of P. obtusa, it is considered a new synonym for P. porophylla. Cervi \&
Rodrigues (2010) considered the print Incertae sedis because they considered that it could not be a synonym of P. pohlii Mast., as designated by Killip (1938), because it appears glabrous in the print, and that it could not be a synonym of P. organensis Gardner, because the flower was not illustrated. Passiflora pohlii occurs in Cerrado (savanna) vegetation, and does not occur in the state of Rio de Janeiro. It differs morphologically from $P$. porophylla because it possesses a moderately to densely pubescent indumentums, and flowers with a corona of biseriate and ligulate filaments.

Passiflora pertusa, only illustrated, shows bilobate leaf blades with ocelli, as does P. rubra, which also has a flower with a corona with uniseriate filaments dialated at the apex. Both species are very similar to $P$. porophylla, as confirmed and synonymized by Cervi \& Rodrigues (2010).

11. Passiflora setacea DC., Prodromus Systematis Naturalis Regni Vegetabilis 3: 329. 1828.

= Passiflora sururuca Vell., Fl. Flumin. 9, fig. 88. 1831 (“1827"); Arch. Mus. Nac. Rio de Janeiro 5: 380. 1881. Lectotype (designated here): Brazil. [Rio de Janeiro]: "fruticetis mediterraneis transalpinis"; [illustration] Original parchment plate of Flora Fluminensis in the Manuscript Section of the Biblioteca Nacional, Rio de Janeiro [cat. no.: mss1198658_092] and later published in Vellozo, Fl. flumin. 9, fig. 88, 1831.

Candole (1828) described P. setacea based on a type material from Rio de Janeiro as having a velutine indumentum; leaves with petioles with two glands; trilobate leaf blades, acute apex, cordate base, serrate margin and ovate bracts. The illustration and description of $P$. sururuca shows a vine with a tomentose indumentums; leaves with petioles with one pair of glands, trilobate leaf blades, acuminate apex, cordate base, serrate margin and lanceolate-ovate bracts; and flowers with aristate sepals and fruit as globose berries. Passiflora sururuca was considered synonymous with $P$. setacea, as already synonymized by Killip (1938) and confirmed by Cervi \& Rodrigues (2010), and according to Vellozo, the taxa occurs in vegetation formations along the Paraíba do Sul river and Mantiqueira Mountains (Serra da Mantiqueira).

12. Passiflora silvestris Vell., Fl. Flumin. 9, fig. 74. 1831 (“1827”); Arch. Mus. Nac. Rio de Janeiro 5: 377. 1881. Lectotype (designated here): Brazil. [Rio de Janeiro]: "campis apricis mediterraneis transalpinis"; [illustration] Original parchment plate of Flora Fluminensis in the Manuscript Section of the Biblioteca Nacional, Rio de Janeiro [cat. no.: mss1198658_078] and later published in Vellozo, Fl. flumin. 9, fig. 74, 1831.

Frequently identified as $P$. galbana Mast., the name $P$. silvestris has priority, as already established by Cervi \& Rodrigues (2010), in accordance with articles 38.8 and 38.9 of Melbourne Code (McNeill et al. 2012). Passiflora silvestris has asymmetrical semicordate stipules; lanceolate-ovate 


\section{Michaele Alvim Milward-de-Azevedo}

leaf blades, acute apex, obtuse to rounded base and entire margin; and oblong ovary and fruits.

13. Passiflora tetraden Vell., Fl. Flumin. 9, fig. 91. 1831 (“1827”); Arch. Mus. Nac. Rio de Janeiro 5: 381. 1881. Lectotype (designated here): Brazil. [Rio de Janeiro or São Paulo]: "silvis maritimis prope urbem"; [illustration] Original parchment plate of Flora Fluminensis in the Manuscript Section of the Biblioteca Nacional, Rio de Janeiro [cat. no.: mss1198658_095] and later published in Vellozo, Fl. flumin. 9, fig. 91, 1831.

Frequently identified as $P$. sidiifolia $\mathrm{M}$. Roem., the name P. tetraden has priority, as already established by Cervi \& Rodrigues (2010), in accordance with articles 38.8 and 38.9 of Melbourne Code (McNeill et al. 2012). Passiflora tetraden has asymmetrical semicordate stipules, leaf blades trilobate to the apex, obtuse apex, rounded base and entire margin; and flowers with banded coronal filaments.

\section{References}

Bediaga B, Lima HC. 2015. A "Flora Fluminensis"de frei Vellozo: uma abordagem interdisciplinar. Boletim Museu Paranaense Emílio Goeldi 10: 85-107.

Borgmeier T. 1937. A história da "Flora Fluminensis" de Frei Velloso. Rodriguésia 9: 77-96.

Braga JMA. 2005. Marantaceae - Novidades taxonômicas e nomenclaturais III: tipificações, sinonímias e uma nova combinação em Calathea. Acta Botanica Brasilica 19: 763-768.

Buzatto CR, Singer RB, Romero-González GA, Berg C, Salazar G. 2013. Typifications and taxonomic notes in species of Brazilian Godyerinae and Spirantthinae (Orchidaceae) described by José Vellozo and Barbosa Rodrigues. Taxon 62: 609-621.

Candole AP. 1828. Passifloraceae. Prodromus systematis naturalis regni vegetabilis 3. Paris, Treuttel et Würtz.

Carauta JPP. 1973. The text of Vellozo's Flora Fluminensis and the effective date of publication. Taxon 22: 281-284

Cervi AC. 1997. Passifloraceae do Brasil. Estudo do gênero Passiflora L. subgênero Passiflora. Fontqueria 45: 1-92.

Cervi AC. 2000. O estudo das Passifloraceae Brasileiras: o subgênero Dysosmioides Killip do gênero Passiflora L. para o Brasil. Estudos de Biologia 45: 91-115.

Cervi AC \& Rodrigues WA. 2010. Nomenclatural and taxonomic review of Passifloraceae species illustrated and described by Vellozo in Flora Fluminensis. Acta Botanica Brasilica 24: 1109-1111.

Curtis W. 1790. Passiflora alata. The Botanical Magazine 1: 66.
Damasceno D. 1977. Veloso, J.M.C. Plantas fluminenses descritas por frei Veloso. Anais da Biblioteca Nacional 96: 123-133.

Killip EP. 1938. The American species of Passifloraceae. Publication Field Museum of Natural History - Botanical Series 19: 1-613.

Knapp S, Barboza GE, Romero MV, Vignoli-Silva M, Giacomin LL, Stehmann JR. 2015. Identification and lectotypification on the Solanaceae from Vellozo's Flora Fluminensis. Taxon 64: 822-836.

Kury LB. 2015. O naturalista Veloso. Revista de História 172: 243-277.

Lack HW. 2012. The Discovery, naming and typification of Bougainvillea spectabilis (Nyctaginaceae). Willdenowia 42: 117-126.

Lamarck JBAPM. 1789. Passiflora mucronata. Encyclopédie Méthodique, Botanique 3: 33 .

Lima HC. 1995. Leguminosas da Flora Fluminensis - J.M. da C. Vellozo - Lista atualizada das espécies arbóreas. Acta Botanica Brasilica 9: 123-146.

Linnaeus C. 1753. Passifloraceae. Species Plantarum 2. Stockholm, Laurentius Salvius.

MacDougal JM, Feuillet C. 2004. Systematics. In: Ulmer T, MacDougal JM. (eds.) Passiflora: Passionflowers of the world. Portland, Oregon, Timber Press. p. 27-31.

McNeill J, Barrie FR, Buck WR, et al. 2012. International code of nomenclature for algae, fungi, and plants (Melbourne Code): adopted by the eighteenth international botanical congress, Melbourne, Australia, July 2011. Regnum Vegetabile 154: 1-208.

Mikan, JC. 1820. Passiflora amethystina. Delectus florae et faunae Brasiliensis. Wien, Vindobonae.

Milward-de-Azevedo MA, Baumgratz JFA, Gonçalves-Esteves V. 2012. A taxonomy revivion of Passiflora subgenus Decaloba (Passifloraceae) in Brazil. Phytotaxa 53: 1-68.

Pastore JFB. 2013. A review of Vellozo's names for Polygalaceae in his Flora Fluminensis. Phytotaxa 108: 41-48.

Pellegrini MOO. 2015. Notes on the Pontoderiaceae names described in Vellozo's Flora Fluminensis. Rodriguésia 66: 913-918.

Pellegrini MOO, Forzza RC, Sakuragui CM. 2015. A nomenclatural and taxonomic review of Tradescantia (Commelinaceae) species described in Vellozo's Flora Fluminensis with notes on Brazilian Tradescantia. Taxon 64: 151-155.

Porter-Utley K. 2014. A revision of Passiflora L. subgenus Decaloba (DC.) Rchb. Supersection Cieca (Medik.) J. M. MacDougal \& Feuillet (Passifloraceae). PhytoKeys 43: 1-224.

Rizzini CT. 1977. Sistematização terminológica da folha. Rodriguésia 42: $103-125$

Sims J. 1818. Passiflora edulis. Curtis's Botanical Magazine 45. London, Sherwood, Neely \& Jones.

Stearn WT. 2004. Botanical Latin. 4th. edn. Portland, Timber Press.

Svoboda HT, MacDougal JM, Ballard Jr HE. 2016. Typifications and nomenclatural notes in Passiflora section Dysosmia (Passifloraceae). Phytotaxa 288: 101-119.

Vellozo JMC. 1831/1881. Passiflora. Tab. 70-95: Flora Flumimensis 9. Paris, A. Senefelder. Text: Archivos do Museu Nacional do Rio de Janeiro 5: 378-381. 